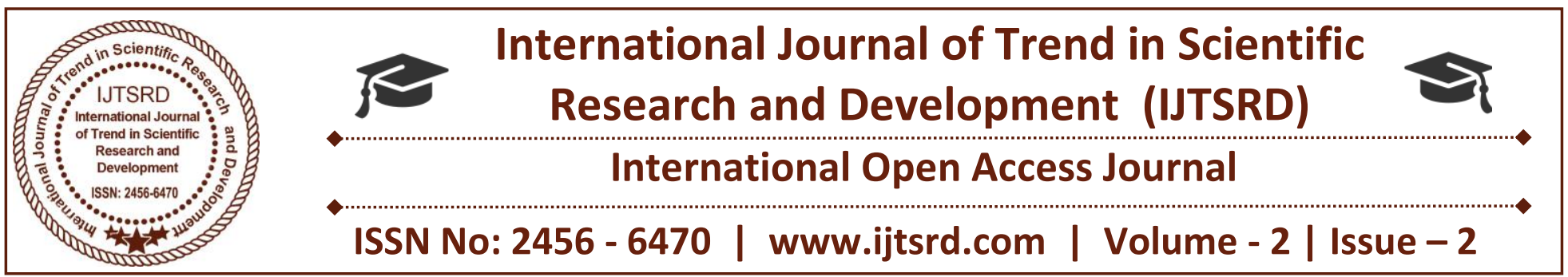

\title{
Chromium-induced growth inhibition and alteration of biochemical parameters in Ocimum basilicum $\mathbf{L}$.
}

\author{
Ruqaya Jabeen \\ Assistant Professor, College of Science and Arts, \\ Addarb, Jazan University, Jazan, KSA
}

\begin{abstract}
The hydroponically grown plants of Ocimum basilicum L. were exposed to varying levels of $\mathrm{K}_{2} \mathrm{Cr}_{2} \mathrm{O}_{7}(0,5,10,25 \mu \mathrm{M})$. The plants were tested for various morphological and biochemical parameters on $3^{\text {rd }}$ and $5^{\text {th }}$ day after treatment. Chromium (Cr) resulted in reduction of plant length and biomass. The deleterious effects of the hexavalent chromium on $O$. basilicum were further confirmed by the reductions in chlorophyll a and b contents, soluble protein and while as the free amino acid and proline contents were increased.
\end{abstract}

The study concludes that chromium causes stress in the Ocimum basilicum plants and thus alters various morphological and biochemical parameters.

\section{Introduction}

Ocimum basilicum is used as antispasmodic, aromatic, carminative and digestive. It has been used to treat fever, abdominal cramps, nausea, migraine, insomnia, depression, dysentery and diarrhea (Marwat et al., 2011). Due to rapid industrial growth, plants are under the stress because of many abiotic stresses. Heavy metal pollution is one of the most vital stresses causing low productivity in plants (Jabeen et al., 2009). Various lethal heavy metals such as $\mathrm{Cd}, \mathrm{Cr}, \mathrm{Ni}$, $\mathrm{Hg}$ etc enter the biosphere from different sources, the most common of which are the metal smelters, emissions from industries as well as indiscriminate use of fertilizers and pesticides in agriculture $\mathrm{(Hu}$ et al., 2013). Heavy metals alter the metabolism in plants. At greater concentrations, these are very toxic and hinder the normal growth of plants. Heavy metals damage the molecular structure of plant cells either directly or by generation of ROS (Diwan et al., 2008), including the free radicals and highly reactive nonradical molecules like $\mathrm{H}_{2} \mathrm{O}_{2}$ and singlet oxygen $\left({ }^{1} \mathrm{O}_{2}\right)$. Chromium $(\mathrm{Cr})$ can prove to be a harmful heavy metal and thus its consequence on plants has been well researched by agricultural scientists. The various other sources of Chromium in the soil are leather tanning industry, textile industry, besides the carpet and electroplating industries (Cao et al., 2017). There is an estimation of about 3550 metric tons anthropogenic release of $\mathrm{Cr}$ in the world fresh water bodies The major two stable chemical forms of chromium in the environment are $\mathrm{Cr}$ (III) and $\mathrm{Cr}$ (VI) amongst which the most toxic is $\mathrm{Cr}$ (VI) because of its carcinogenic properties (Wang et al., 2012).

$\mathrm{Cr}$ phytotoxicity causes a decrease in the seed germination, reduced root growth, induces chlorosis in leaves and reduces biomass (Vajpayee et al., 2001). It can degrade the photosynthetic pigments, cause nutrient balance, enhance the antioxidant enzymes, and induce the oxidative stress in plants in addition to causing a change in the ultrastructure of membrane and chloroplast (Ashfaque et al., 2017).

However, plants are naturally blessed with a defense system which comprises of enzymatic and nonenzymatic antioxidants which defends the different important physiological processes from damage by the ROS released in the plants under heavy metal stresses (Rai et al., 2004). The various enzymatic antioxidants are superoxide dismutase, catalase and glutathione transferase, various enzymes of 
Ascorbate-Glutathione cycle like ascorbate peroxidase, glutathione reductase. Ascorbate and glutathione, the non-enzymatic components of the antioxidative defense system have been known to increase under metal stress (Diwan et al., 2008)

This study was aimed at finding the effect of chromium on the growth and biochemical parameters of the plant. Further studies on the antioxidant defense system of the plants under various chromium treatments and the concentration of chromium in various plant parts of the treated plants need to be done to ensure whether the plant defense system can render the plant resistance against heavy metal stress. The screening of the plant for chromium effect on the secondary metabolite of this medicinal plant will ensure the possibility of using this plant for chromium phytoremediation in affected soils.

\section{Materials and Methods:}

\section{Plant description:}

Ocimum basilicum $\mathrm{L}$. is an annual herbaceous plant from the Lamiaceae family. It is used as a spice, drug, and tea etc. It has many phytochemicals and has been used against digestive ailments, rheumatoid arthritis, depression, paralysis, cough and many other problems.

\section{Plant Culture:}

Seeds of Ocimum basilicum L were collected from the lawns of College of Science and Arts, Addarb, Jazan University, Saudi Arabia. They were grown on petridishes using filter paper and seedlings of almost same size were transferred to Hoagland's nutrient solution which contained $3 \mathrm{mM} \mathrm{KNO}_{3}, 1 \mathrm{mM}$ $\mathrm{NH}_{4} \mathrm{H}_{3} \mathrm{PO}_{4}, 50 \mu \mathrm{M} \mathrm{KCl}, 2 \mathrm{mM} \mathrm{Ca}\left(\mathrm{NO}_{3}\right) 2,25 \mu \mathrm{M}$ $\mathrm{H}_{3} \mathrm{BO}_{3}, 2 \mu \mathrm{M} \mathrm{ZnCl}, 2 \mu \mathrm{M} \mathrm{MnCl}_{2}, 0.5 \mu \mathrm{M}$ ( NH4) 6 $\mathrm{MO}_{7} \mathrm{O}_{24}, 0.5 \mu \mathrm{M} \mathrm{CuCl}_{2}, 1 \mathrm{mM} \mathrm{MgSO}_{4}$ and $20 \mu \mathrm{M}$ $\mathrm{Na}_{2}$ FeEDTA, and $\mathrm{pH}$ of this nutrient medium was maintained at $6.5 \pm 0.1$ by $\mathrm{NaOH}$. 10-day old seedlings were treated with 5,10 and $25 \mu \mathrm{M} \mathrm{K}_{2} \mathrm{Cr}_{2} \mathrm{O}_{7}$ while as the plants without any chromium concentration served as a control. Seedlings were analyzed for various parameters on $3^{\text {rd }}$ and $5^{\text {th }}$ days after treatment.

\section{A. Growth Parameters:}

The 10-day old seedlings of Ocimum basilicum $L$. were treated with various doses of chromium and the plants were harvested three and five days after treatment. The whole plant length was measured in ' $\mathrm{cm}$ ' while as the plant biomass was measured in ' $\mathrm{g}$ ' for control and treated plants.

\section{B. Biochemical parameters:}

\section{Pigment concentrations}

Hiscox and Israelstam's (1979) method was used to estimate the pigment concentration in the samples.

The method involves the estimation of plant pigments without maceration. Leaves were washed with distilled water (DDW) and chopped. $100 \mathrm{mg}$ of chopped leaf material was taken in vials in triplicates and $10 \mathrm{ml}$ of Dimethyl sulphoxide was added to each vial which was heated in oven at $65^{\circ} \mathrm{C}$. After $30 \mathrm{~min}$, the vials were taken out and the OD of the solution was measured at 663 and $645 \mathrm{~nm}$.

\section{$12.3\left(\mathrm{~A}_{663}\right)-0.86\left(\mathrm{~A}_{645}\right)$}

$$
\begin{array}{cc}
\text { Chlorophyll } a\left(\mathrm{mg} \mathrm{g}^{-1} \mathrm{fw}\right)=\frac{\mathrm{d}}{\mathrm{d} \times 1000 \times \mathrm{W}} & \mathrm{x} \\
\text { Chlorophyll } b\left(\mathrm{mg} \mathrm{g}^{-1} \mathrm{fw}\right)=\frac{19.3\left(\mathrm{~A}_{645}\right)-3.60\left(\mathrm{~A}_{663}\right)}{\mathrm{d} \times 1000 \times \mathrm{W}} & \mathrm{x} \mathrm{V}
\end{array}
$$

Where $\mathrm{d}=$ distance traveled by the light path, $\mathrm{W}=$ weight of the leaf material taken, $\mathrm{V}=$ volume of the extract and $\mathrm{A}=$ Absorbance 
2. Soluble protein content: Bradford

(1976) protocol was used for protein estimation.

\section{Reagent preparation:}

\section{(a) Extraction buffer (0.1-M/ pH 7.2 Phosphate buffer)}

The solution of $0.1 \mathrm{M}$ monobasic potassium phosphate $\left(\mathrm{KH}_{2} \mathrm{PO}_{4}\right)$ was made by mixing $1.36 \mathrm{~g}$ of $\mathrm{KH}_{2} \mathrm{PO}_{4}$ in DDW and volume was completed to 100 ml. $0.1 \mathrm{M}$ dibasic potassium phosphate $\left(\mathrm{K}_{2} \mathrm{HPO}_{4}\right)$ solution was made by dissolution of $1.74 \mathrm{~g}$ of $\mathrm{K}_{2} \mathrm{HPO}_{4}$ in DDW and volume was made to $100 \mathrm{ml}$. Two components of the buffer were mixed in an appropriate amount to maintain the $\mathrm{pH}$ of buffer 7.2 that was monitored with the $\mathrm{pH}$ meter.

\section{(b) $10 \%$ Trichloroacetic acid (TCA)}

$10 \mathrm{~g}$ of TCA was mixed in DDW to a total volume of $100 \mathrm{ml}$.

(c) $0.1 \mathrm{~N}$ - Sodium hydroxide $(\mathrm{NaOH})$

$0.4 \mathrm{~g}$ of $\mathrm{NaOH}$ was mixed in DDW to a total volume of $100 \mathrm{ml}$.

\section{(d) Bradford's reagent}

$100 \mathrm{mg}$ of Comassie brilliant blue G-250(CBBG-250) was mixed in $50 \mathrm{ml}$ of $90 \%$ ethanol. Add $100 \mathrm{ml}$ of $85 \%$ O-phosphoric acid to this solution and stirr well on a magnetic stirrer. This was diluted to a final volume of $1000 \mathrm{ml}$ with DDW and again stirred well. This solution was filtered carefully in dark by using Whatmann filter Paper No. 42 to remove the undissolved particles of dye. The final concentration of ingredients was $0.01 \%$ CBBG-250, $4.75 \%$ ethanol and $8.5 \%$ O- phosphoric acid.

\section{Procedure:}

$0.2 \mathrm{~g}$ of fresh and clean and chopped leaf material was homogenized in $2 \mathrm{ml} 0.1 \mathrm{M} / \mathrm{pH} 7.2$ phosphate buffer with the help of a pre-cooled mortar and pestle. Homogenate was transferred to the pre-cooled centrifuge tube and the centrifugation was done at $5000 \mathrm{rpm}$ for $10 \mathrm{~min} .1 .0 \mathrm{ml}$ of supernatant was added to equal amount of chilled $10 \%$ Trichloroacetic acid (TCA) in a microfuge. It was centrifuged for $10 \mathrm{~min}$ at $3300 \mathrm{rpm}$ and the supernatant obtained was thrown while as the remaining pellet was washed with acetone. $1 \mathrm{ml}$ of $0.1 \mathrm{~N} \mathrm{NaOH}$ was used to dissolve the pellet. $0.5 \mathrm{ml}$ Bradford's reagent was added to $0.1 \mathrm{ml}$ aliquot and was subjected to vortex. The tubes were left to let the color develop for $10 \mathrm{~min}$. OD was taken at $595 \mathrm{~nm}$ on spectrophotometer.

BSA was used as the standard to calculate protein concentrations and the protein content was expressed as $\mathrm{mg} \mathrm{g}^{-1} \mathrm{FW}$.

\section{Free Amino Acids}

The estimation of free amino acids was done by the method of Lee and Takahashi's method (1966).

\section{Reagent preparation:}

\section{(a) Citrate buffer $(0.5 \mathrm{M} / \mathrm{pH} 5.5)$}

$0.5 \mathrm{M}$ citric acid solution was prepared by dissolving $52.339 \mathrm{~g}$ citric acid in DDW and volume was made to $500 \mathrm{ml}$. $0.5 \mathrm{M}$ sodium citrate solution was prepared by dissolving $73.53 \mathrm{~g}$ of sodium citrate in DDW and volume was made to $500 \mathrm{ml}$. Two components of the buffer were mixed in an appropriate amount to maintain the $\mathrm{pH}$ of buffer 5.5 and was monitored with the $\mathrm{pH}$ meter.

\section{(b) $55 \%$ Glycerol}

It was made by dissolving $55 \mathrm{ml}$ of glycerol to $45 \mathrm{ml}$ of DDW.

\section{(c) $1.0 \%$ Ninhydrin solution}

Ninhydrin solution was prepared by mixing $1 \mathrm{~g}$ ninhydrin in $0.5 \mathrm{M}$ citrate buffer to a final volume of $100 \mathrm{ml}$.

\section{Procedure:}

Fresh chopped leaves of weight $0.5 \mathrm{~g}$ were homogenated in $5 \mathrm{ml}$ absolute ethanol and were poured in to the centrifuge tubes. Centrifugation was done for $10 \mathrm{~min}$ at $5000 \mathrm{rpm}$ at temperature of $4^{\circ} \mathrm{C}$. The supernatant was heated for $1 \mathrm{hr}$ at $80^{\circ} \mathrm{C}$ so that the alcohol gets evaporated. $10 \mathrm{ml} 0.5 \mathrm{M} / 5.5 \mathrm{pH}$ citrate buffer was used to dissolve the pellet. $0.5 \mathrm{ml}$ aliquot from this was added to $0.5 \mathrm{ml}$ Ninhydrin and $1.5 \mathrm{ml} 55 \%$ Glycerol. The vials were heated at $100^{\circ} \mathrm{C}$ for 20 minutes and a purple colour was noticed. The final volume was made $6 \mathrm{ml}$ with the addition of citrate buffer. The blue color appeared remain stable for $1 \mathrm{hr}$. Optical density was measured at $570 \mathrm{~nm}$ on spectrophotometer.

The standard curve was made by using Glycine solution as the standard and the results were expressed as $\mathrm{mg} \mathrm{g}^{-1} \mathrm{FW}$. 


\section{Proline Content}

Proline content estimation was done by the protocol of Bates et al. (1973).

\section{Reagent preparation:}

\section{(a) $3 \%(w / v)$ Sulphosalicylic acid}

$3 \mathrm{~g}$ of Sulphosalicylic acid was mixed in DDW to make a volume of $100 \mathrm{ml}$.

\section{(b) 6 N Orthophosphoric acid}

It was prepared by mixing $38.10 \mathrm{ml}$ of Orthophosphoric acid in $61.90 \mathrm{ml}$ of DDW.

\section{(c) Ninhydrin solution}

$1.25 \mathrm{~g}$ ninhydrin was added to $30 \mathrm{ml}$ GAA in addition to $20 \mathrm{ml} 6 \mathrm{~N}$ orthophosphoric acid and agitated continuously till dissolved. The total volume was made $100 \mathrm{ml}$ by adding distilled water.

\section{Procedure:}

Fresh leaves of weight $0.5 \mathrm{~g}$ were ground by mortar and pestle. Centrifugation of the mixture was done for $10 \mathrm{~min}$ duration at $5000 \mathrm{rpm}$. The $0.2 \mathrm{ml}$ supernatant was added to $2 \mathrm{ml}$ ninhydrin and $2 \mathrm{ml} \mathrm{GAA}$. The solution was boiled at $100^{\circ} \mathrm{C}$ and later transferred to ice bath to stop the reaction. Each test tube was added with $4 \mathrm{ml}$ of toluene and vortexed for 10-15 $\mathrm{sec}$ in order to facilitate quick diffusion / movement of chromophores from the aqueous phase to non-aqueous phase. The upper layer of toluene was transferred to a cuvette and OD was taken at $520 \mathrm{~nm}$ on spectrophotometer using toluene as blank. The standard curve was made by using L-proline as a standard and the results were recorded by the unit mg $\mathrm{g}^{-1} \mathrm{FW}$.

\section{Results and discussion}

\section{Growth Parameters}

Growth parameters of Ocimum basilicum were studied by the parameter of whole plant length and the plant dry weight. The results of these parameters are shown in figure 1 and 2 . Chromium treatments resulted in decrease of whole plant at both the stages of sampling. The highest decrease was found at $\mathrm{Cr}-25$ which was $29.29 \%$ and $65.76 \%$ on 3 and 5 days of treatment respectively. Plant biomass was not affected by $\mathrm{Cr}-5$ treatment but the increase in treatment dose reduced the plant biomass by maximum $54.13 \%$ at $\mathrm{Cr}-25$ on $3^{\text {rd }}$ day after treatment. At $5^{\text {th }}$ day after treatment, a gradual decrease was noticed in the plant biomass with the maximum $(78 \%)$ recorded at $\mathrm{Cr}-25$ treatment. Our results were in conformity with the results of Vajpayee et al. (2001) who noticed a similar Cr-inhibited growth in Vallesneria spirralis L. plants. The inhibited growth due to chromium treatments may be because of inhibited cell division (Diwan et al., 2008).

\section{Pigment Concentrations}

The chlorophyll $\mathrm{a}$ and $\mathrm{b}$ contents were measured and recorded in figures 3 and 4 . Three days after treatment, the chlorophyll a content was increased by Cr-10 treatment and decreased with other treatments. The maximum $21 \%$ decrease was found with $\mathrm{Cr}-25$ treatment. Five days after treatment, there was a decrease irrespective of the chromium treatments, the maximum decrease was recorded at $\mathrm{Cr}-10(46 \%)$. Chlorophyll $b$ showed a decrease with all $\mathrm{Cr}$ treatments except at $\mathrm{Cr}-10$ concentration where it showed an increase of $18 \%$ at 3DAT while as on 5DAT, it showed a gradual decrease except at $\mathrm{Cr}-5$ while it showed a slight $(3 \%)$ increase. This falls in line with the study of Appenroth et al. (2003) in the plant Spirodela polyrhiza. The decrease in pigment concentration may be due to the degradation of animo-levulinic acid dehydratase, which in turn causes a reduction in prophobilinogen necessary for chl biosynthesis, thereby affecting the amino levulinic acid (ALA) utilization.

\section{Soluble Protein Content:}

Chromium treatments caused a decrease in the soluble protein content (Fig 5). The maximum percentage decrease was found with $\mathrm{Cr}-25$ on both the days of sampling, 3DAT and 5DAT. The respective percentage decrease was $56 \%$ and $57 \%$ for 3DAT and 5DAT. Similar decrease in soluble protein content was witnessed by Vajpayee et al. (2001) in Vallesneria spiralis. The decrease in the soluble protein content may be because of increased proteolysis under stress.

\section{Free Amino Acid:}

Free amino acid content saw a gradual increase on 3DAT where it ranged from 0.4-6\% from $\mathrm{Cr} 5-\mathrm{Cr} 25$ (Fig 6). On fifth day of sampling, maximum increase was found with Cr-10 (35\%). Diwan et al. (2012) also witnessed an increase in free amino acid content in Brassica juncea plants when subjected to $\mathrm{Cr}$ stress. 
The reason for increased free amino acid content may be either due to decreased protein synthesis or increased proteolysis.

\section{Proline Content:}

Proline content in response to various $\mathrm{Cr}$ stresses showed a gradual increase on 3DAT (6-44\%) while as on 5DAT, the content was maximum (24\%) at Cr-25 concentration (Fig 7). Alia and Saradhi (1991) have also acquired similar increase in proline accumulation in response to heavy metal stress. Plants respond various stresses by inducing accumulation of some metabolites, the most obvious are generally amino acid and proline in particular (Aleksza et al., 2017)

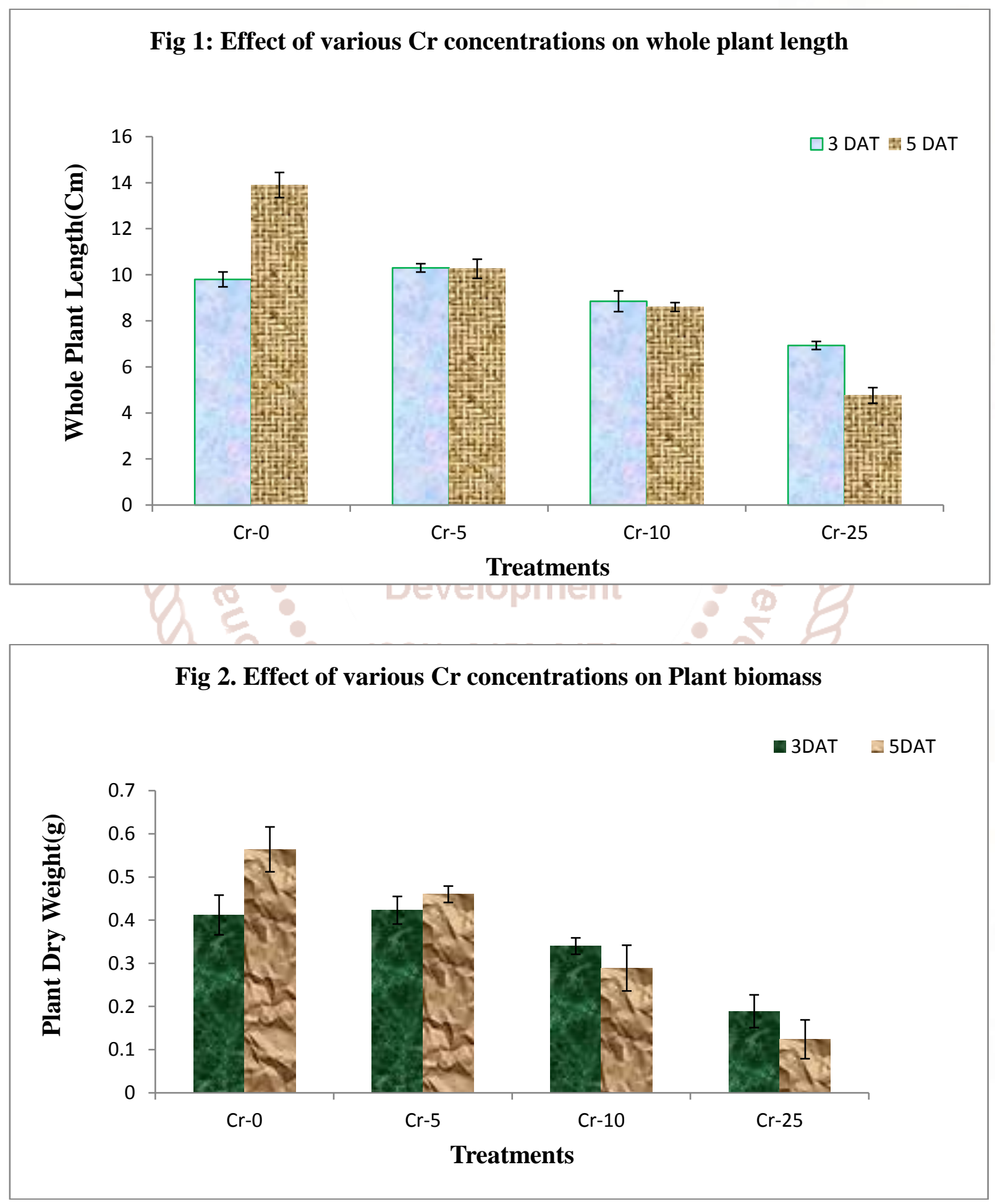



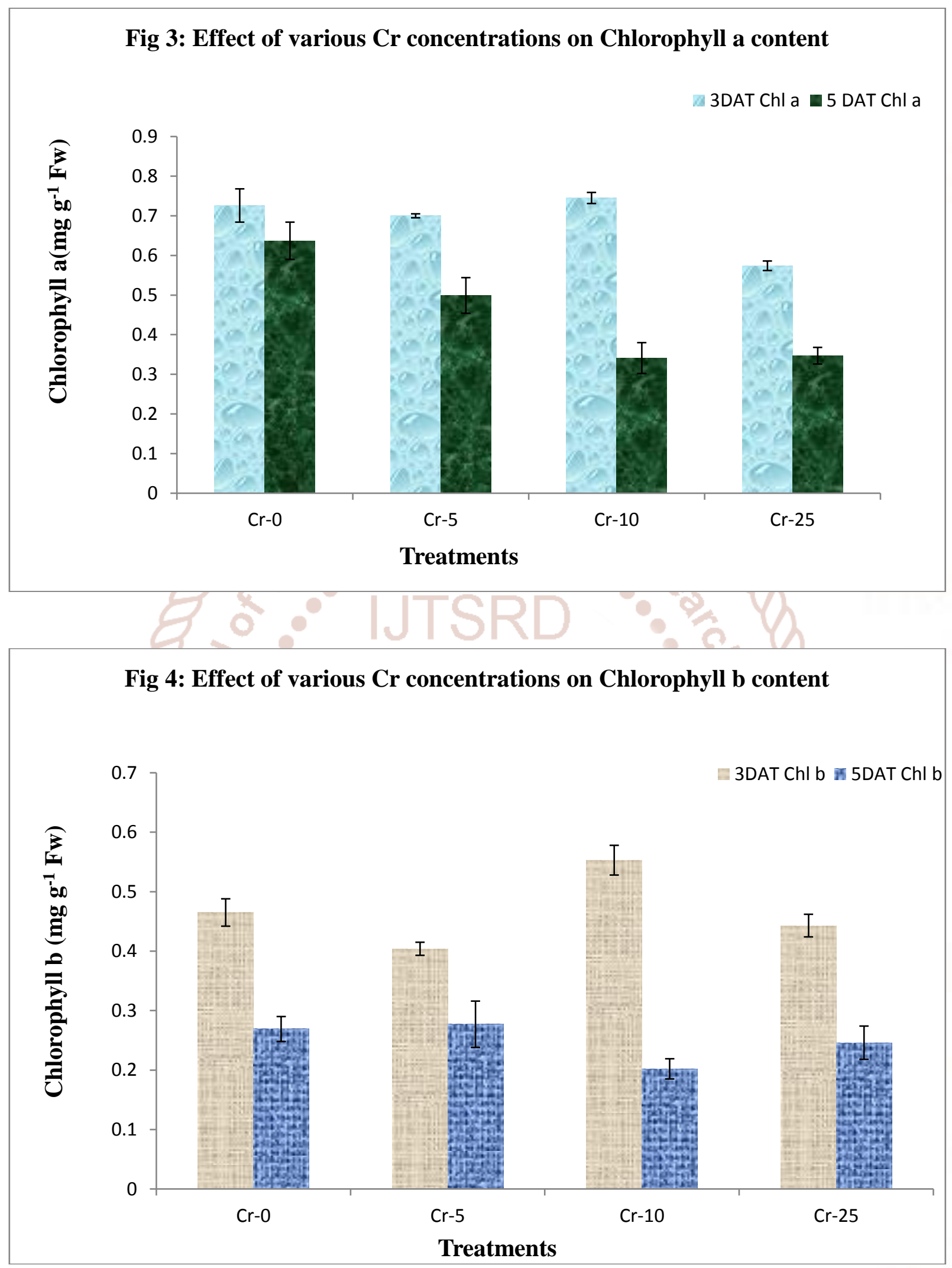
Fig 5: Effect of various Cr concentrations on Soluble Protein content

3 DAT 5 DAT

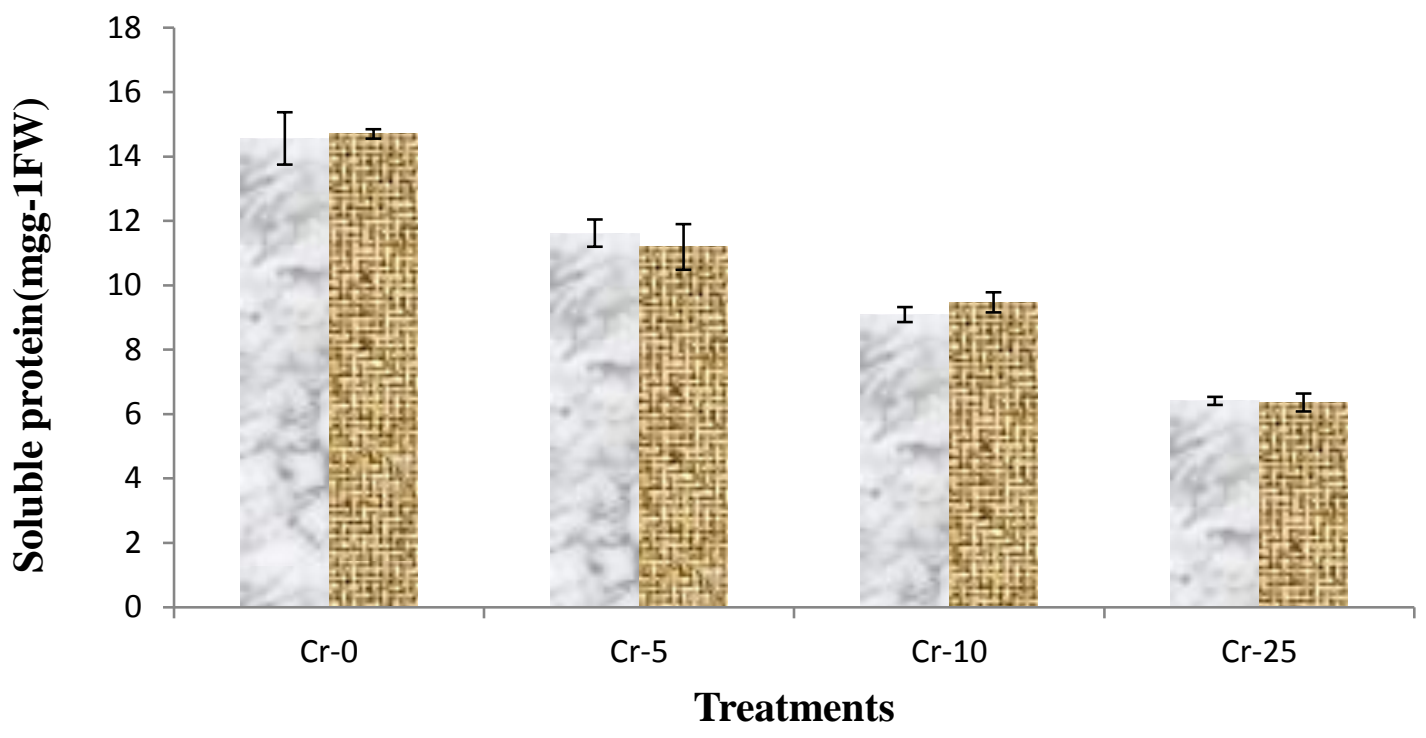

Fig 6: Effect of various Cr concentrations on Free Amino acid content

A 3 DAT 5 DAT
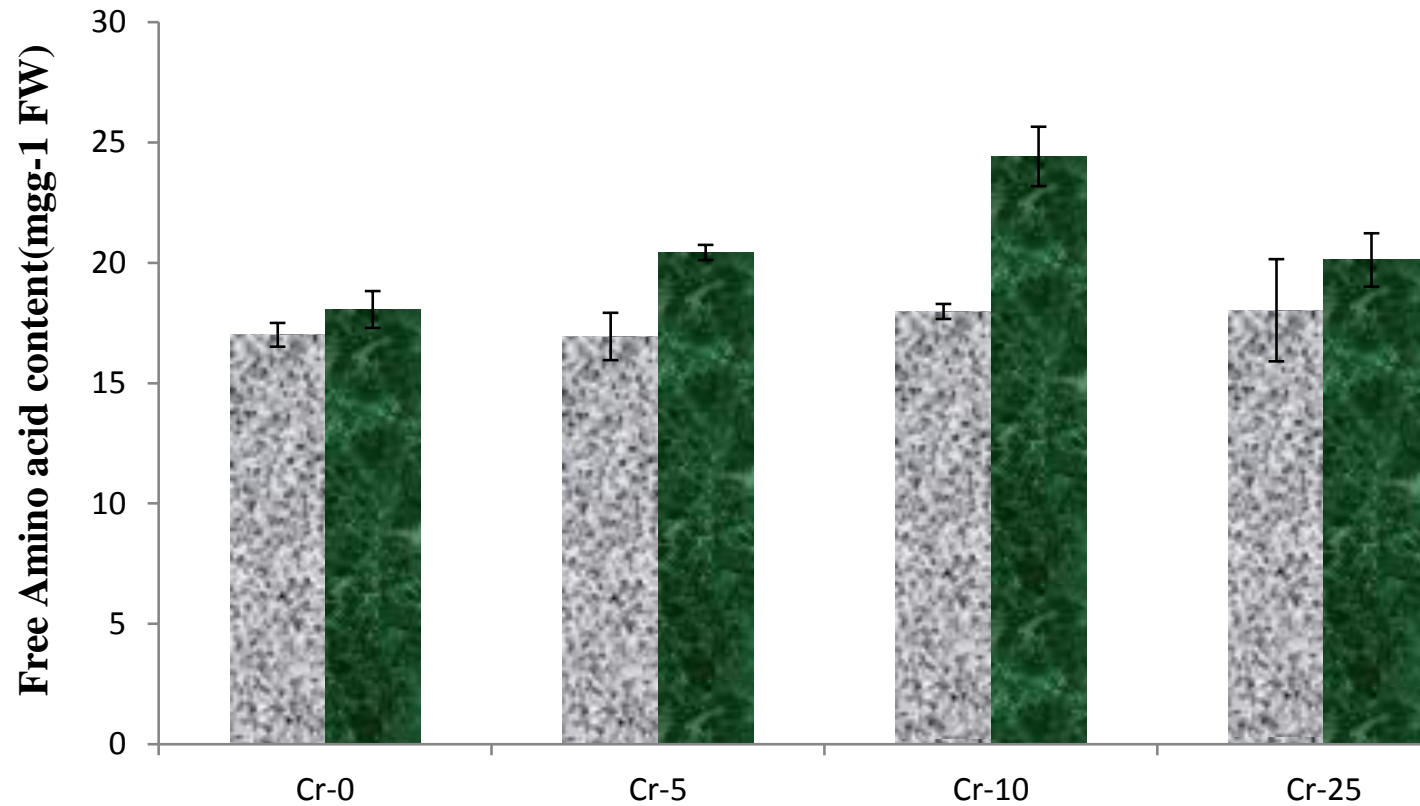

Cr-10

Cr-25

Treatments 


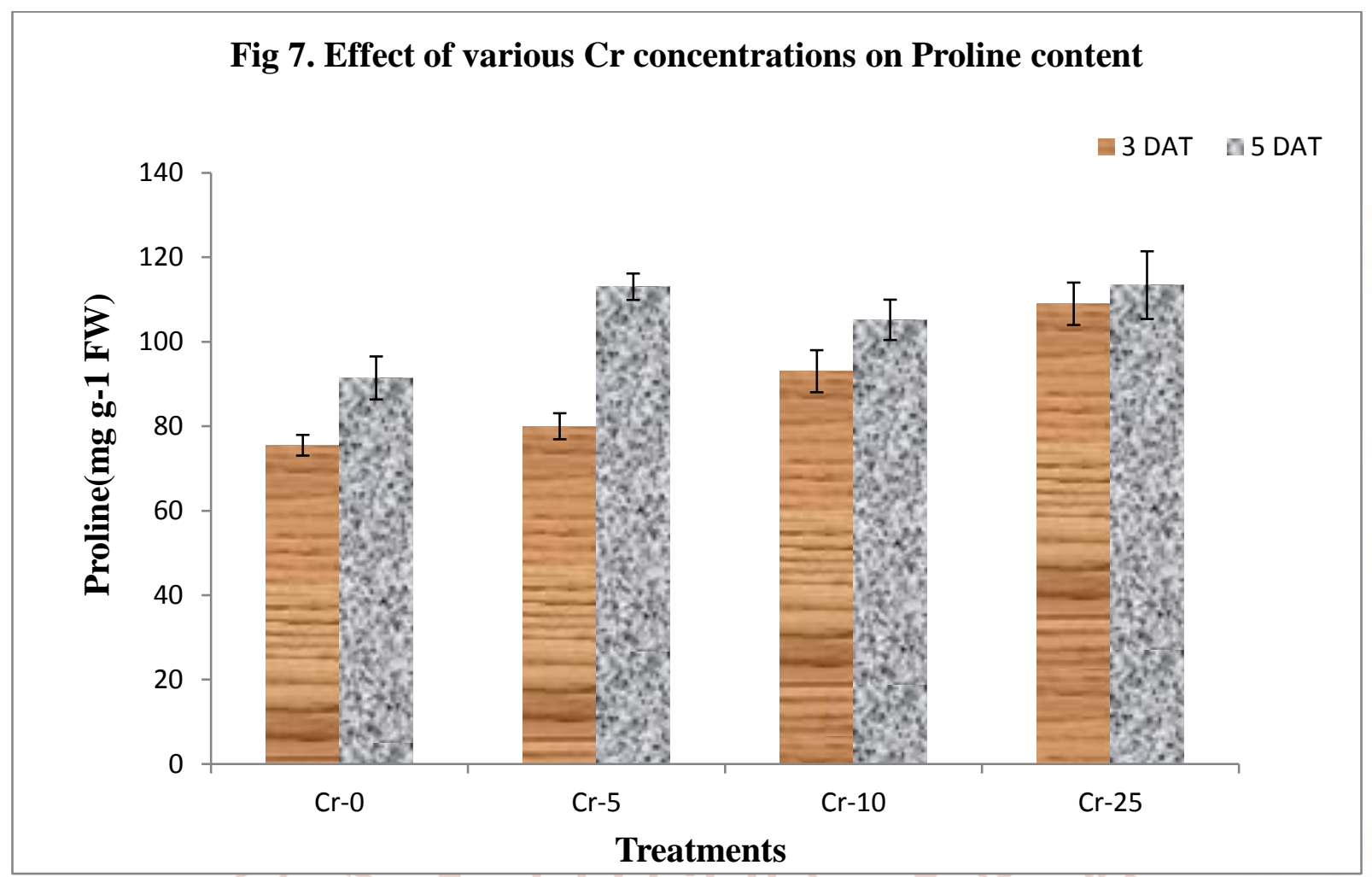

\section{Conclusion:}

From this study, we conclude that Chromium affects the growth and biochemical parameters in Ocimum basilicum. The magnitude of the effect is directly proportional to the amount of stress imposed at different growth stages of the plants. Further studies on the antioxidant defense system of the plants under various chromium treatments and the concentration of chromium in various plant parts of the treated plants need to be done to ensure whether the plant defense system can render the plant resistance against heavy metal stress. The screening of the plant for chromium effect on the secondary metabolite of this medicinal plant will ensure the possibility of using this plant for chromium phytoremediation in affected soils.

\section{References}

1. Ackerson RC (1981) Osmoregulations in cotton in response to water stress. II. Leaf carbohydrate status in relation to osmotic adjustment. Plant Physiol 67: 489-493.

2. Aleksza Dávid, Horváth Gábor V., Sándor Györgyi, Szabados László (2017). Proline Accumulation Is Regulated by Transcription Factors Associated with Phosphate Starvation. Plant Physiology. 175:53-64
3. Alia, Pardha Saradhi P (1991). Proline accumulation under heavy metal stress. J. Plant Physiol. 138: 554-558.

4. Appenroth KJ, Keresztes A, Sarvari E, Jaglarz A, Fischer W (2003). Multiple effects of chromate on Spirodela polyrhiza: electron microscopy and biochemical investigations. Plant Biol. 5: 315323.

5. Ashfaque F, Inam A, Inam S, Iqbal S, Sahay S (2017). Response of silicon on metal accumulation, photosynthetic inhibition and oxidative stress in chromium-induced mustard (Brassica juncea L.). South African Journal of Botany 111:153-160.

6. Bates LS, Waldren RP, Teare ID (1973) Rapid determination of free proline for water stress studies. Plant and Soil 39: 205-207.

7. Bradford MM (1976) A rapid and sensitive method for the quantitation of microgram quantities of protein utilizing the principle of protein-dye binding. Analytical Biochem 72: 248259.

8. Cao Fengmei, Liu Haiteng, Wu Fengchang, Lu Shaoyong (2017). Automated Determination of Chromium (VI) in Tannery Effluent Using Flow Injection Analysis with an Optical Flow Cell and Detector. Water, Soil and Air Pollution 228-232. 
9. Diwan H, Ahmed A, Iqbal M (2008). Genotypic variation in the phytoremediation potential of Indian mustard for chromium. Environ. Manag. 29: 473-478.

10. Hiscox JD, Israelstam GF (1979) A method for extraction of chlorophyll from leaf tissue maceration. Can J Bot 57: 1332-1334.

11. Hu W, Huang B, Shi X, Chen W, Zhao Y, Jiao W (2013). Accumulation and health risk in a plotscale vegetable production system in a peri-urban vegetable farm near Nanjing, China. Ecotoxicol. Environ. Safety. 98: 303-309.

12. Jabeen R, Ahmad A, Iqbal M. Phytoremediation of Heavy Metals: Physiological and Molecular Mechanisms. The Botanical Review. 2009;75:339-364.

13. Lee LP, Takahashi $\mathrm{T}$ (1966). An improved colorimetric determination of amino acids with the use of ninhydrin. Anal. Biochem. 14:71-77.
14. Marwat SK, Khan MA, Rehman FU, Akbari AH, Shoaib M, Shah MA (2011). Interprettaion and medicinal potential of Ar-rehan (Ocimum basilicum L.)-a review. American-Eurasian J. Agric. \& Environ Sci. 10(4): 478-484.

15. Rai V, Vajpayee P, Singh SN, Mehrotra S (2004). Effect of chromium accumulation on photosynthetic pigments, oxidative stress defense system, nitrate reduction, proline level and eugenol content of Ocimum tenuiflorum L. Plant Science 167: 1159-1169

16. Vajpayee P, Rai UN, Ali MB, Tripati RD, Yadav V, Sinha S, Singh SN (2001). Chromium-induced physiologic changes in Vallisneria spiralis L. and its role in phytoremediation of tannery effluents. Bull. Environ. Contam. Toxicol. 67: 246-256.

17. Wang Z, Liu R, Liu J (2012). Trivalent chromium: A neglected latent contaminant. Vitam. Trace Elem.1:4

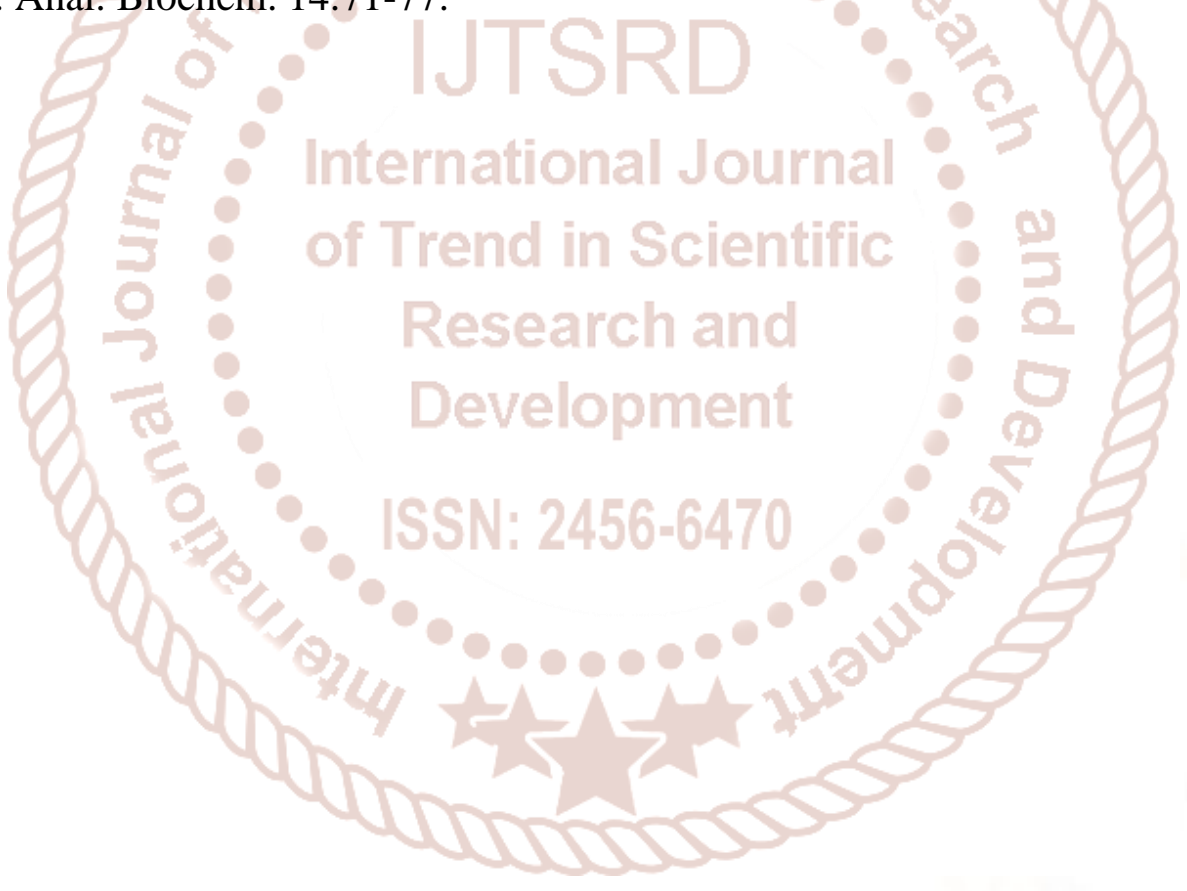

